„FOLIA BIBLIOLOGICA” (2013/2014), VOL. LV/LVI

\title{
Helena Choraczyńska
}

Instytut Bibliotekoznawstwa i Informacji Naukowej UMCS w Lublinie

\section{GENEZA HISTORII LITERATURY POLSKIEJ FELIKSA BENTKOWSKIEGO}

The Origin of History of Polish Literature [Historia literatury polskiej] by Feliks Bentkowski

\begin{abstract}
The article discusses the origin of the Historia literatury polskiej wystawionej $w$ spisie dziet drukiem ogłoszonych [History of Polish Literature presented in the list of published works] (Warsaw Vilna, t. 1-2, 1814) because of this year's bicentennial anniversary of its publication. The study presents the political situation in the capital of the Duchy of Warsaw, which largely influenced the development of Polish literary historiography, and discusses the initiatives undertaken by the Warsaw Society of Friends of Science community aimed to write and publish a handbook of history of Polish literature. The paper names and characterizes the profiles of authors who were commissioned to prepare the handbook in question. The circumstances of compilation of the History of Polish Literature, whose author was finally to be F. Bentkowski, were shown: the book was initially intended as a school handbook but was finally published as a monumental two-volume work. The concepts of several scholars were analyzed concerning the probable date of when Bentkowski started to prepare the synopsis of History of Polish Literature, and the factors and other works that prompted him to begin work on the book in question. The scholarly methodology employed by F. Bentkowski when gathering materials for the future History of Polish Literature (i.e. research in the book collections of six libraries, including five in Warsaw) was presented and the bibliographic materials made available to him by other scholars, upon which he drew while working on the book, were specified. It was emphasized that the History of Polish Literature [Historia literatury polskiej] brought Bentkowski fame, awards, and honors, but despite its favorable reception in Warsaw's academic community and its great significance for bibliography and Polish literature, it id not have a second edition in the $19^{\text {th }}$ century. It was reissued only once in the $1980 \mathrm{~s}$.
\end{abstract}

Wydarzenia polityczne XIX wieku wytyczyły w dużym stopniu kierunek rozwoju polskiej historiografii literackiej. Upadek państwa polskiego przyczynił 
się do podjęcia na szeroką skalę akcji zmierzającej do utrzymania i pogłębienia świadomości narodowej Polaków. A jedną z głównych dróg prowadzących do wspomnianego celu miało być poznanie własnego piśmiennictwa. Na początku wieku pojawiły się zatem apele o to, by opracować całość dziejów literatury polskiej na użytek powszechny ${ }^{1}$.

Tego rodzaju postulat znajdujemy na kartach opublikowanych w 1801 roku Myśli o pismach... Adama Kazimierza Czartoryskiego. Wyrażał on potrzebę „wydania historyi krytycznej literatury polskiej, która by zajmowała w sobie uwiadomienia bibliograficzne, o celniejszych pisarzach, rozebranie ich dzieł, i zdanie o nich rozumowane", a autor tego przedsięwzięcia, jak stwierdzał sam Czartoryski, zdobyłby sobie uznanie Polaków².

W kręgach Towarzystwa Warszawskiego Przyjaciół Nauk, z którego wywodził się Czartoryski, żywo interesowano się dawnym piśmiennictwem polskim. Rezultatem tych zainteresowań było pojawienie się, już od roku 1803, potrzeby opracowania oraz wydania podręcznika historii literatury. Tego roku Jan Nepomucen Kossakowski na jednym z posiedzeń Towarzystwa zgłosił projekt ogłoszenia konkursu na dzieło poświęcone dziejom literatury polskiej i sam zobowiązał się złożyć odpowiednią kwotę tytułem nagrody ${ }^{3}$. Zdaniem Jerzego Korpały nie doszło jednakże ani do ogłoszenia konkursu, ani do napisania podręcznika ${ }^{4}$.

Jak pisze Stanisław Makowski, dwa lata później (tj. w 1805 roku) Stanisław Staszic, wygłosiwszy swoje Myśli o ksiązkach najpożyteczniejszych na jednym z posiedzeń Towarzystwa Przyjaciół Nauk, zalecił Wydziałowi Literatury m.in. opracowanie podręcznika historii literatury polskiej na wzór dzieła Jeana-François de La Harpe' ${ }^{5}$, dając w ten sposób wyraz troski Towarzystwa o język narodowy.

${ }^{1} \mathrm{Na}$ taki kierunek rozwoju historii literatury zwrócił uwagę R. Skręt w swej rozprawie habilitacyjnej Historiografia literatury polskiej w XIX stuleciu, Wrocław 1986, s. 5.

${ }^{2}$ Myśli o pismach polskich. Z uwagami nad sposobem pisania w rozmaitych materyach, Wilno 1801, przedruk fotooffsetowy, Warszawa 1981, s. 168-169. Na karcie tytułowej brak podanego autora; pod dedykacją do Ignacego Potockiego widnieje podpis: A. Dantiscus to jest Adam Kazimierz Czartoryski. Czartoryski w przypisie podał, iż wzorem dla historii literatury miałby być kurs literatury Lycée ou Cours de littérature ancienne et moderne wydany w roku $1786 \mathrm{w} 18$ tomach, autorstwa Jeana-François de La Harpe'a, ibid., s. 169. Por. F. H. Lewestam, hasło: Laharpe, [w:] Encyklopedia powszechna Orgelbranda, t. 16, Warszawa 1864, s. 627.

3 R. Skręt, op. cit., s. 5; S. Makowski, Feliks Bentkowski 1781-1852, [w:] Z dziejów polonistyki warszawskiej. Profesorowi Julianowi Krzyżanowskiemu w dwudziesta piąta rocznice objęcia Katedry Historii Literatury Polskiej na Uniwersytecie Warszawskim 1934-1959, Warszawa 1964, s. 120, przypis 17.

4 J. Korpała, Dzieje bibliografii w Polsce, Warszawa 1969, s. 104.

5 Jean-François de La Harpe tytuł swego dzieła zaczerpnął od nazwy instytucji Lycée. Owo Liceum paryskie założone w 1781 roku początkowo pod nazwą Musée, pierwotnie było szkołą praktycznych nauk technicznych i przemysłu, z czasem stało się instytucją dla inteligencji chcącej 
Jednakże według Tadeusza Sterzyńskiego projekt opracowania historii literatury polskiej nie zrodził się bynajmniej po raz pierwszy w łonie Towarzystwa Przyjaciół Nauk. Jak zauważył badacz, miało to miejsce znacznie wcześniej jeszcze bowiem za czasów Rzeczypospolitej dyskutowano na ten temat w gronie Jana Andrzeja Załuskiego i Daniela Jana Janockiego ${ }^{6}$.

Po kilku latach (zdaniem Sterzyńskiego niedługo po ogłoszeniu konkursu na dzieło poświęcone literaturze narodowej) ${ }^{7}$ zlecenie przygotowania takiego podręcznika powierzono Cyprianowi Godebskiemu, poecie, członkowi Towarzystwa od roku 1805, współwydawcy „Zabaw Przyjemnych i Pożytecznych”. Podjąwszy to zlecenie, Godebski ,zrobił rozkład na epoki i zaczął stosownie do planu zbierać wzorowe materiały". Niestety śmierć w bitwie pod Raszynem przerwała jego prace. Tadeusz Sterzyński (a za nim Rościsław Skręt) stwierdził, iż niemal jednocześnie z Godebskim Towarzystwo Przyjaciół Nauk wezwało Ignacego Potockiego do napisania podobnego dzieła. Ten zaś, podejmując się tego zadania, ,z niezmierną pracą zebrał i ułożył materiały do [...] historii literatury polskiej" ${ }^{8}$. Jednakże burzliwa sytuacja kraju nie pozwoliła na ukończenie zamierzonych przez niego prac; po jego śmierci materiały rękopiśmienne zaginęły ${ }^{9}$. Jak pisał Makowski, pomimo śmierci Godebskiego Towarzystwo z powziętego zamiaru nie zrezygnowało, gdyż w jego ramach podejmowano dalsze inicjatywy w tym kierunku. Według Sterzyńskiego jedną z takich inicjatyw była propozycja Niemcewicza, który w mowie wygłoszonej w roku 1808 na posiedzeniu Towarzystwa Przyjaciół Nauk zwrócił

uzupełnić swe wykształcenie. Tu prelegentem był La Harpe, wykłady rozpoczął w 1786 i prowadził do 1798 roku, kiedy to zostały przerwane z powodu wypadków politycznych; od 1794 roku wznowione w postaci nowego cyklu, które La Harpe prowadził do 1798 roku. La Harpe był z zawodu literatem, protegowanym Woltera, próbującym swych sił w twórczości dramatycznej, członkiem Akademii Francuskiej. Jego Kurs literatury (Lycée ou Cours de littérature...), jak pisze Maurycy Mann, był trzecim dziełem, które zdobyło wielki rozgłos jako metodyczny zbiór wiadomości o literaturze powszechnej z uwzględnieniem francuskiej. W Kursie... La Harpe pokrótce omówił literaturę starożytną, przeskakując następnie do wieku Ludwika XIV i właśnie klasycyzm francuski, literatura okresu od połowy XVII do końca XVIII wieku, stanowi właściwie jego przedmiot. La Harpe, zdając sobie sprawę z braku prawdziwej historii literatury, chciał swym dziełem ten brak uzupełnić. Jednakże Kurs... nie odpowiadał wymaganiom syntezy historycznoliterackiej, bowiem zastosowany w nim niezręczny podział na rodzaje zakłócał porządek chronologiczny jako podstawę każdej historii. Zob. S. Makowski, Feliks Bentkowski 1781-1852..., s. 120, przypis 17; M. Mann, Rozwój syntezy literackiej. Od jej początków do Gervinusa, odbitka z „Rozpraw Wydziału Filologicznego Akademii Umiejętności w Krakowie”, Kraków 1911, t. 48, s. 72-76.

${ }^{6}$ T. Sterzyński, Feliks Bentkowski jako historyk literatury, maszynopis w dziale starodruków Biblioteki KUL w Lublinie, s. 14, 16-17.

${ }^{7}$ Ibid., s. 12.

8 J. Ursyn Niemcewicz, Pochwała pogrzebowa Ignacego Potockiego, „Roczniki Towarzystwa Królewskiego Warszawskiego Przyjaciół Nauk” 1812, t. 8, cz. 2, s. 117, cyt. za: R. Skręt, op. cit., s. 6.

9 T. Sterzyński, op. cit., s. 13. 
uwagę, aby zajęło się ono ,utworzeniem porządnego i rozumowanego katalogu dzieł polskich, od dawnych czasów aż do dzisiejszego wieku w języku naszym wydanych" ${ }^{\prime 10}$.

W roku 1813 Stanisław Staszic wysunął podobną propozycję, aby zajęto się opracowaniem pojedynczych rozpraw poświęconych poszczególnym gatunkom literackim, z których miało powstać dzieło obejmujące całokształt literatury pięknej. Kilku członków Towarzystwa podjęło prace, przedkładając już w następnym roku swe rozprawy. Pomimo starań Staszica, do roku 1821 prac tych nie udało się skompletować i projekt upadł ${ }^{11}$.

Należy podkreślić, że w rok po zleceniu Godebskiemu przygotowania podręcznika (najprawdopodobniej w roku 1806) w kręgach literackich zainteresowanie wywołała rozprawa Kazimierza Chromińskiego zatytułowana $O$ literaturze polskiej, mianowicie czasów Zygmuntowskich, to jest złotego wieku pisarzy ${ }^{12}$, erudyty, który był dobrze obeznany z historią kultury europejskiej XVI wieku. Celem Chromińskiego było przypomnienie świetnej epoki piśmiennictwa polskiego, której ramy określił datami 1504 i 1638, a oceniał wysoko, wskazując na „geniusz Polaków”, który wówczas objął Europę i ,świetnością swoją zabłysnął”. Na poparcie swych twierdzeń cytował sporą liczbę wypowiedzi obcych pisarzy, przytaczał przykłady pierwszeństwa i wyższości Polaków nad innymi narodami. Zawarte w tytule słowo „literatura” rozumiał bardzo szeroko. Włączał w jej zakres nie tylko piśmiennictwo i język, ale i całą kulturę epoki, a mianowicie muzykę, teatr, drukarzy, szkoły, biblioteki, a nawet sztukę i kopalnictwo ${ }^{13}$.

Jak pisze Jerzy Korpała, zainteresowanie wspomnianą rozprawą w kołach literackich spowodowane było brakiem w tym czasie prac krytycznych i historycznoliterackich ${ }^{14}$. Sterzyński i Skręt uznali rozprawę Chromińskiego za pierwszą tego rodzaju w piśmiennictwie polskim. Była ona zachętą i ostatecznym bodźcem, które popchnęły Feliksa Bentkowskiego - ówczesnego historyka literatury - do

10 Ibid., s. 15.

11 S. Makowski, Feliks Bentkowski 1781-1852.., s. 120, przypis 17; J. Korpała, Dzieje bibliografii w Polsce..., s. 104; hasło: Godebski Cyprian, [w:] Wielka encyklopedia powszechna $P W N$, t. 64, Warszawa 1964, s. 296.

${ }^{12}$ K. Chromiński był pracownikiem Biblioteki Załuskich, a potem także nauczycielem liceum w Wilnie oraz współpracownikiem Ignacego Potockiego. Jego wspomniana rozprawa opublikowana została w „Dzienniku Wileńskim” w roku 1806 i osobno w odbitce pt. Rozprawa o literaturze polskiej, Wilno 1806. Zob. R. Skręt, op. cit., s. 6; T. Sterzyński, op. cit., s. 17. Rozprawę Chromińskiego omawia krótko bardzo pochlebnie Bentkowski w wykazie dzieł do historii literatury i bibliografii polskiej potrzebnych we wstępie do swej Historii literatury polskiej $w$ spisie dziet drukiem ogłoszonych przez..., Warszawa-Wilno 1814, t. 1, s. 62.

13 R. Skręt, op. cit., s. 6-7.

14 J. Korpała, Dzieje bibliografii w Polsce..., s. 104. 
energicznego zbierania materiałów do swej przyszłej Historii literatury polskiej. Świadczą o tym jego własne słowa, które dosyć precyzyjnie pomagają określić datę przystąpienia do opracowania tego monumentalnego dzieła. W autobiografii zawarł on bowiem informację, iż jego dzieło było „owocem ośmioletniej pracy”. Kierując się tym stwierdzeniem, Sterzyński założył, że skoro Bentkowski ukończył je w pierwszych miesiącach 1814 roku, należy wnosić, iż do gromadzenia materiału musiał przystąpić z początkiem 1807 roku, zatem tuż po prawdopodobnym zapoznaniu się z rozprawą Chromińskiego ${ }^{15}$.

Odmiennego zdania był Tadeusz Szperna, według którego punktem wyjścia do pracy Bentkowskiego nad przyszłą Historiq literatury polskiej było dziełko profesora berlińskiej Akademii Wojskowej Tomasza Szumskiego Krótki rys historii literatury polskiej od najpóźniejszych do teraźniejszych czasów (Berlin 1807). Szperna wysnuł taki wniosek na podstawie licznych odręcznych uwag, komentarzy, dopełnień bibliograficznych oraz indeksów autorskich i rzeczowych dokonanych przez Bentkowskiego, widniejących na interfoliowanym egzemplarzu rozprawy Szumskiego znajdującym się w Archiwum Akt Dawnych w Warszawie. Jak zauważył Szperna, Bentkowski podobne skorowidze sporządził na końcu dwóch innych prac o charakterze bibliograficznym, a mianowicie: Szymona Starowolskiego Scriptorum Polonicorum Hekatontas (wyd. 3 z 1734 roku) i Dawida Brauna De scriptorum Poloniae et Prussiae historicorum... (1723) ${ }^{16}$.

Do przyczyn, jakie wpłynęły na zainicjowanie przez Bentkowskiego pracy nad Historiq literatury polskiej, Sterzyński zaliczył czynniki patriotyczne, głównie zwrot ku przeszłości, czego wyrazem była wciąż odczuwana potrzeba stworzenia historii literatury polskiej jako historii narodowej. Jego zdaniem istniały także pobudki natury naukowej. Do nich należy zaliczyć wpływ atmosfery naukowej uniwersytetu halskiego, a w szczególności wykłady Augusta Fryderyka Wolffa z historii literatury greckiej i łacińskiej, który zajmował się wyczerpująco i w sposób nowatorski zagadnieniem historii literatury, podkreślając jej znaczenie i doniosłość w ogólnym systemie wiedzy. Stąd można przypuszczać, iż wykłady Wolffa wzbudziły w Bentkowskim bliższe zainteresowanie się historią literatury ${ }^{17}$. Podobne pobudki i oddziaływania naukowe miały wpływ na Bentkowskiego, płynąc podług Sterzyńskiego z drugiego ośrodka halskiego, mianowicie z redakcji

15 T. Sterzyński, op. cit., s. 17-19; T. Szperna przyjął rok 1806 za datę przyjęcia zamysłu opracowania Historii literatury polskiej przez Bentkowskiego. Zob. T. Szperna, Ksztattowanie się bibliograficznych zainteresowań Feliksa Bentkowskiego, „Acta Universitatis Lodziensis. Folia Librorum" 1999, nr 9, s. 70.

16 T. Szperna, Ksztattowanie się bibliograficznych zainteresowań Feliksa Bentkowskiego..., s. 71.

17 T. Sterzyński, op. cit., s. 2-4. 
„Allgemeine Literatur Zeitung”. Wspomniane czasopismo reprezentowało wysoki poziom naukowy i cieszyło się dużym autorytetem nie tylko w niemieckim, ale nawet w europejskim ruchu naukowym.

W zamieszczanych w nim recenzjach niejednokrotnie podnoszono doniosłość historii literatury. Samo czasopismo, dzięki swemu układowi, mogło uchodzić za uzupełnienie podręczników do historii literatury powszechnej, stanowiąc przegląd krytyczny ówczesnego piśmiennictwa. Zatem za pośrednictwem „Allegemeine Literatur Zeitung" Bentkowski zetknął się z najnowszym ruchem naukowym europejskim, zwłaszcza zaś z niemieckim ${ }^{18}$.

Do wspomnianych powyżej czynników natury patriotycznej i naukowej, które miały wpływ na powstanie głównego dzieła Bentkowskiego, doszedł jeszcze czynnik nowy, mianowicie konkretne potrzeby szkolnictwa Księstwa Warszawskiego, a mówiąc ściślej brak podręcznika do literatury polskiej dla użytku szkolnego ${ }^{19}$. W tej sytuacji Towarzystwo do Ksiąg Elementarnych postanowiło powierzyć Bentkowskiemu opracowanie takowego podręcznika dla klas VI szkół wojewódzkich (prawdopodobnie na wniosek Samuela Bogumiła Lindego jako członka tego Towarzystwa). W tym celu na sesji z 16 października 1811 roku Towarzystwo to wystosowało do niego pismo następującej treści:

Wiedząc z jaką gorliwością W. J. P. Bentkowski profesor Liceum Warszawskiego pracuje w zbieraniu bibliografii polskiej, gdy podług planu nauk na szkoły departamentowe, w klasie VI, krótki rys literatury polskiej dawać wypada, a do tego koniecznie potrzebna jest książka dla uczniów, wzywa GO, aby się chciał ułożeniem takowego zatrudnić i Towarzystwo w tej mierze uwiadomiće ${ }^{20}$.

Wymienione Towarzystwo domagało się zatem zwięzłego podręcznika o charakterze wybitnie syntetycznym, Bentkowski zaś, nie dostrzegłszy początkowo zasadniczej rozbieżności między intencjami Towarzystwa a charakterem zebranego przez siebie materiału, ochoczo podjął się nałożonego nań zadania, żywiąc przeświadczenie, iż gruntowność prac przygotowawczych oraz dotychczasowa praktyka pedagogiczna pozwolą mu sprostać zaufaniu instytucji. Dlatego też w liście z 28 października 1811 roku adresowanym do Towarzystwa do Ksiąg Elementarnych pisał:

Na odezwę Prześwietnego Towarzystwa Elementarnego, abym się ułożenia dzieła o literaturze polskiej, dla klasy VI szkół departamentowych służyć mogące, zatrudnił, mam honor odpowiedzieć, iż wszelkiej przyłożę usilności, aby chlubnem dla mnie wezwaniu Prześ. Towarzystwa zadosyć uczynił... ${ }^{21}$.

\footnotetext{
18 Ibid., s. 4-6.

19 Ibid., s. 19-20.

${ }^{20}$ Cyt. za: T. Sterzyński, op. cit., s. 22-23.

${ }^{21}$ Cyt. za: ibid., s. 24.
} 
Propozycja Towarzystwa do Ksiąg Elementarnych z 1811 roku $^{22}$ skierowana do Bentkowskiego zbiegła się $\mathrm{w}$ czasie $\mathrm{z}$ objęciem przez niego funkcji kierownika biblioteki Liceum Warszawskiego. Miał już wówczas sporo zgromadzonych materiałów oraz gotowy konspekt wykładów o literaturze ${ }^{23}$. Konspekt ten, zaadaptowany i wzbogacony o ogromny materiał bibliograficzny, utworzył pierwszy tom przyszłego dzieła ${ }^{24}$. W związku $\mathrm{z}$ tym Linde w swym sprawozdaniu na rok 1810/1811 podał pierwszą informację, iż zebrane z różnych źródeł wiadomości o piśmiennictwie polskim Bentkowski zamierza wydać drukiem ${ }^{25}$.

Makowski w swych rozważaniach dotyczących genezy Historii literatury polskiej Bentkowskiego przyjął, iż była ona związana z pracami, jakie pierwotnie prowadził on we wspomnianym Liceum. Na początku nowego roku szkolnego, tj. 15 września 1809 roku, Bentkowski otrzymał w tymże liceum stanowisko profesora literatury polskiej po Konstantym Wolskim (któremu powierzono stanowisko dyrektora Wydziału Ksiąg Elementarnych w Izbie Edukacyjnej) ${ }^{26}$. Jak uznał Szperna, Bentkowski już wcześniej, bo w czasie wakacji, w sierpniu tegoż roku, przewidując pomyślne dla siebie rozwiązanie całej sprawy (tj. objęcie zwolnionego przez kolegę etatu) przygotował Plan. „Historii literatury polskiej”, który posłużył mu do opracowania ramowego konspektu wykładów z literatury pięknej ${ }^{27}$.

${ }^{22}$ Zdaniem J. Korpały sugestie A. K. Czartoryskiego skłoniły Towarzystwo do Ksiąg Elementarnych do podjęcia inicjatywy opracowania podręcznika do historii literatury i w tej sprawie zwrócono się do Bentkowskiego, proponując mu opracowanie takowego podręcznika.

${ }^{23}$ Początkowa faza pracy nad Historiq literatury polskiej zbiegła się nie tylko z objęciem posady bibliotekarza w Liceum Warszawskim, ale także z zapoczątkowaniem nowego okresu rozwoju księgarstwa i bibliografii w Polsce przez Jerzego Samuela Bandtkiego, który opublikował broszurę o inkunabułach krakowskich pt. De Primus Cracoviae in arte typographica incunabulis, Kraków 1812. Dziełko Bandtkiego uprzytomniło Bentkowskiemu doniosłość badań nad dziejami drukarstwa i piśmiennictwa, a także ukazało mu ogrom trudności pojawiających się na drodze naukowego opracowania dziejów literatury. Trudności te tym bardziej potęgował fakt, iż nie było studiów przygotowawczych ani krytyki literackiej. Wynikało to z opóźnienia w rozwoju i organizacji nauki polskiej. Zob. J. Korpała, Zarys dziejów bibliografii w Polsce, Wrocław 1953, s. 53.

${ }^{24}$ Zdaniem Korpały konspekt dzieła Bentkowskiego stanowił anonimowy rękopis znajdujący się w Bibliotece Czartoryskich w Krakowie, sygn. 3265, pt. O literaturze polskiej. Por. J. Korpała, Dzieje bibliografii $w$ Polsce..., s. 105 przypis 5; jak dodaje Makowski rękopis ów pochodzący ze zbiorów rejenta sieradzkiego Andrzeja Pstrokońskiego z Baryczy liczył 163 strony tekstu. Por. S. Makowski, Feliks Bentkowski 1781-1852..., s. 116, przypis 14. Por. T. Szperna, Kształtowanie się bibliograficznych zainteresowań Feliksa Bentkowskiego..., s. 72, przypis 25.

25 S. Makowski, Feliks Bentkowski 1781-1852.., s. 116.

${ }^{26}$ Bentkowski, zdaniem Tadeusza Sterzyńskiego, do swej przyszłej pracy literackiej rozpoczął poszukiwanie wzorów już około 1806 roku, a może i wcześniej. Zob. T. Sterzyński, op. cit., s. 25; J. Bieliński, Królewski Uniwersytet Warszawski 1816-1831, t. 3, Warszawa 1912, s. 527.

27 T. Szperna, Ksztattowanie się bibliograficznych zainteresowań Feliksa Bentkowskiego..., s. 72 , przypis 24 . 
Na przełomie lat 1808/1809 dla klasy VI Bentkowski opracował krótki rys literatury polskiej ,,przez wszystkie wieki”, jednakże jego dopracowanie przełożył na rok następny. Ze sprawozdania Lindego, dyrektora nadmienionego liceum, za rok 1809/1810 dowiadujemy się, jak wyglądał program nauczania tego przedmiotu.

Uczniowie tej klasy [VI] zebrali już wprawdzie w klasach niższych cząstkowe wiadomości o pisarzach ojczystych, lecz tutaj dopiero daje się historia literatury polskiej w całej obszerności, wystawieniem stanu nauk przez wszystkie wieki i każdej umiejętności w szczególe, wymieniając pisarzy i dzieła podług klasyfikacji zachowanej w dziele p. Carlankas [de Carlencas] pod tytułem Historia nauk wyzwolonych ${ }^{28}$. Naprzód wyłuszczył nauczyciel urządzenia, środki i okoliczności, które się przyczyniły do wzrostu cywilizacji i zakwitnienia nauk, jako też i przeszkody, których powszechne oświecenie lub pojedyncze nauki w narodzie naszym doznawały. Po takowym wstępie wymienił pisma, z których wiadomości o historii literatury naszej zasięgnąć można. Podzieliwszy potem całą historię literatury na pięć okresów, wystawił obraz stanu nauk przez wszystkie wieki, starając się osobliwie o dokładne oznaczenie panującego gustu i rozmaitych kolei, których język polski i powszechne oświecenie za rządów każdego monarchy doznawało. Dalej mówił o najdawniejszych pomnikach języka polskiego tak wierszem, jak prozą, o dziełach traktujących o języku polskim w ogólności i w szczególności. Prócz tego ukończono w tym roku historią poezji ojczystej we wszystkich jej oddziałach, przyłączając zawsze wiadomości bibliograficzne jako do historii literatury niezbędnie potrzebne. W roku następnym dalszy będzie ciąg a mianowicie historia nauk filozoficznych, matematycznych, historycznych i nauk przyrodzenia ${ }^{29}$.

Na podstawie treści tego programu można wywnioskować, że zakres historii literatury polskiej nie pokrywał się z dzisiejszym jej rozumieniem. W rzeczywistości była to nauka obszerna, o charakterze encyklopedycznym, która obejmowała piśmiennictwo ze wszystkich dziedzin wiedzy, a więc również dzieje nauki i oświa-

${ }^{28}$ Przytoczone dzieło Feliksa de Juvénela de Carlencasa pt. Historia nauk wyzwolonych, Warszawa 1766, jak podaje S. Makowski ukazało się w jednym tomie w przekładzie polskim dokonanym przez jezuitę Franciszka Górskiego pod patronatem komendanta Korpusu Kadetów A. K. Czartoryskiego, który przeznaczył je ,ad usum Korpus Kadetów”. Obejmowało ono tylko fragmenty z dzieła czterotomowego zatytułowanego Essai sur l'histoire des sciences, des belles-lettres et des arts, Lyon 1749, dotyczące literatury, krasomówstwa i historii. W dziele tym klasyfikacja pisarzy została dokonana na zasadzie klasycznego (poetyki klasycznej) podziału na rodzaje i gatunki literackie. Po krótkich definicjach gatunków autor wyliczał pisarzy według narodowości tych, którzy dany gatunek uprawiali. Od tłumacza dodane zostały informacje o pisarzach polskich oraz trafne, syntetyczne oceny ich dzieł. Tłumacz Carlencasa, inspirowany przez Czartoryskiego, pomijał w zasadzie element biograficzny pisarzy, koncentrując się przede wszystkim na utworach. Jeśli chodzi o twórczość, to miejscami próbował oceniać ją pod kątem zasług i roli poszczególnych pisarzy w rozwoju danego gatunku literackiego. Tłumaczenie to stanowiło usystematyzowany zbiór wiadomości o pisarzach polskich, dawało pierwszy zarys literatury polskiej. Stąd ponad pięćdziesiąt lat używano go w szkołach, a późniejsi historycy literatury niejednokrotnie powoływali się na nie i wskazywali jako wzór. Można powiedzieć, że był to pierwszy w Polsce zarys literatury ojczystej i powszechnej. Zob. S. Makowski, Feliks Bentkowski 1781-1852..., s. 116; idem, O najdawniejszych podręcznikach historii literatury polskiej. Z polskich tradycji metodycznych, „Polonistyka” 1961, R. 14, nr 2, s. 26-27.

${ }^{29}$ Na publiczny popis uczniów Warszawskiego Liceum... Warszawa 1810, cyt. za: S. Makowski, Feliks Bentkowski 1781-1852..., s. 115-116. 
ty. Najczęściej formułowanym postulatem metodycznym w programach nauczania było zalecenie, by pedagodzy informowali uczniów o życiu i twórczości omawianych na lekcjach pisarzy i autorów. Bentkowski, realizując te wytyczne, jednocześnie wzbogacał wykłady o wyniki własnych badań nad dziejami piśmiennictwa polskiego, zapoznając obszernie słuchaczy z tajnikami wiedzy bibliograficznej. Dowodem na to, że poruszał problemy z zakresu bibliografii, było sprawozdanie licealne Lindego z roku następnego. Dowiadujemy się z niego, iż Bentkowski podczas wykładów zapoznawał uczniów z dotychczasowym dorobkiem w dziedzinie bibliografii, prezentując im przegląd wszystkich najważniejszych prac z tego zakresu. Omówił więc najbardziej znane dzieła z polskiej bibliografii, tj.: Starowolskiego, Janockiego, Oloffa, Załuskiego, Brauna, Jabłonowskiego, Hoffmana, Czackiego, w dalszej kolejności wskazał prace mało znane w bibliografii i historii literatury polskiej, m.in. Andrzeja Węgierskiego, zawierające informacje o piśmiennictwie kalwińskim Systema historico-chronologicum Eccllesiarum Slavonicarum czy zbiór opracowanych biografii świątobliwych mężów Forteca duchowna Hiacynta Pruszcza. Zwrócił również uwagę na przydatne do bibliografii pozycje autorów zagranicznych: Christiana Gottlieba Jochera Allgemeines Gelehrten-Lexicon, Johanna Friedricha Echarda Bibliotheca ordinis praedicatorum czy Alegambego Bibliotheca sriptorum Societatis Jesu.

Wobec powyższego Szperna uznał, iż prelekcje Bentkowskiego były pierwszymi w naszym kraju wykładami z dziejów bibliografii polskiej, a jego działalność, choć prekursorska, pozostawała jak dotąd niezauważona. Natomiast zdaniem Korpały Bentkowski miał świadomość, że napisanie podręcznika historii literatury musiało być poprzedzone opracowaniem bibliografii ${ }^{30}$, dlatego przystąił do zbierania materiałów, które w zasadzie gromadził osobiście w ówczesnych bibliotekach krajowych.

Korzystał przede wszystkim z biblioteki Liceum Warszawskiego, a będąc jej kierownikiem, mógł swobodnie czerpać z zasobnego księgozbioru (który to znacznie powiększył m.in. dzięki znajomości z ówczesnym dyrektorem Biblioteki Jagiellońskiej Jerzym Samuelem Bandtkiem, poprzez wymianę dubletów czy dzięki zapisom testamentowym - tak na przykład został przekazany księgozbiór Kazimierza Chromińskiego). Także dogodnym polem do działań badawczych była dla Bentkowskiego otwarta w 1811 roku do użytku publicznego biblioteka Towarzystwa Przyjaciół Nauk, która posiadała pokaźny księgozbiór. Bentkowski czerpał materiały również z innych bibliotek: Biblioteki Publicznej przy Sądzie

${ }^{30} \mathrm{~W}$ początkach XIX wieku, kiedy granice między bibliografią a historią literatury były jeszcze płynne, a w zakresie przedmiotu badań i stosowanych metod obie dyscypliny przez długi czas wykazywały wiele podobieństw, Bentkowski potrafił dostrzec różnice między tymi pojęciami i był świadom zakresu zadania. Por. J. Korpała, Dzieje bibliografii w Polsce..., s. 106. 
Apelacyjnym prowadzonej przez Mateusza Kozłowskiego ${ }^{31}$, księży misjonarzy kierowanej przez Michała Szymonowicza, pijarskiej kierowanej przez Szymona Bielskiego oraz puławskiej Czartoryskich, którą prowadził Jan Kruszyński po Godfrydzie Erneście Grodku.

Materiały do Historii literatury polskiej pochodzą ze wspomnianych bibliotek oraz źródeł bibliograficznych drukowanych i rękopiśmiennych. Informacje o nich zawarto w przedmowie do jej tomu pierwszego. Wśród nich są adnotacje od Jana Kruszyńskiego o rzadkich dziełach znajdujących się w Puławach ${ }^{32}$.

${ }^{31}$ Mateusz Kozłowski (1764-1834), bibliotekarz, towarzyszył Tadeuszowi Czackiemu w jego bibliofilsko-kolekcjonerskich podróżach po kraju, co pozwoliło mu zdobyć orientację bibliograficzną w piśmiennictwie polskim i obcym. Zapewne wówczas ocalił, kopiując w kilku egzemplarzach, znajdujący się w posiadaniu Czackiego rękopis Załuskiego pt. Biblioteka historyków, prawników, polityków i innych autorów polskich lub o Polsce piszacych, który w roku 1832 wydał w Krakowie Józef Muczkowski. Rękopis ten Bentkowski wykorzystywał w postaci licznych cytatów w swej Historii literatury polskiej. W roku 1812 został powołany na stanowisko bibliotekarza i archiwisty Biblioteki Publicznej przy Sądzie Apelacyjnym w Warszawie, która miała stanowić publicznie dostępną bibliotekę narodową. Jednakże ciasnota pomieszczenia, w jakim umieszczono księgozbiór, uniemożliwiła jego uporządkowanie. Księgozbiór obejmował do 20 tysięcy książek i rękopisów. Mimo to Kozłowski starał się udostępniać zbiory pracującym naukowo, m.in. Bentkowskiemu i Lelewelowi.

W roku 1817 księgozbiór wcielono do biblioteki organizowanej przy powstającym w Warszawie uniwersytecie, Kozłowskiego natomiast zwolniono z posady. Następnie był pośrednikiem w sprzedaży książek, które dostarczał m.in. do Biblioteki Publicznej przy Uniwersytecie Warszawskim. Był pomocnikiem Tytusa Adama Działyńskiego, który zakładał bibliotekę w Kórniku pod Poznaniem. Od czasu do czasu organizował w Warszawie licytacje starych druków. Był znany jako bibliograf. Jako erudyta o dobrej pamięci służył pomocą bibliograficzną wielu piszącym, m.in. F. Bentkowskiemu, K. W. Wójcickiemu. Zob. I. Treichel, hasło: Kozłowski Mateusz, [w:] Polski słownik biograficzny, t. 15, Wrocław 1970, s. 23. Kilka informacji o powstaniu Biblioteki przy Sądzie Apelacyjnym. Feliks Łubieński, minister sprawiedliwości za czasów Księstwa Warszawskiego, zgromadził spore zbiory biblioteczne w pałacu biskupa krakowskiego niedaleko Sądu Apelacyjnego, skąd powstała nazwa: Biblioteka przy Sądzie Apelacyjnym. W jej skład weszły: rodzinny księgozbiór Łubieńskich, zasoby klasztorów skasowanych w czasach pruskich, kolekcja Anzelma Speizera, bibliotekarza Biblioteki Jagiellońskiej czy część druków z zasobów klasztornych benedyktynów w Sieciechowie. Po uzyskaniu w roku 1810 zgody księcia Fryderyka Augusta na założenie biblioteki publicznej przy Sądzie Apelacyjnym Łubieński zaczął kompletować jej księgozbiór. Zob. J. Korpała, Dzieje bibliografii $w$ Polsce..., s. 107; J. Grycz, Historia ksiązki i bibliotek w zarysie, Warszawa 1972, s. 80; E. Słodkowska, Biblioteki w Królestwie Polskim 1815-1830, Warszawa 1996, s. 15.

32 Jan Kruszyński (1773-1845), poeta, tłumacz, działacz insurekcji kościuszkowskiej. W latach 1804-1812 był kustoszem zbiorów w Świątyni Sybilli w Puławach, powołanym przez Izabelę Czartoryską. Zajmował się tam również biblioteką. Utrzymywał żywe stosunki ze światem literackim Warszawy. Tłumaczył dla teatru utwory dramatyczne. Zob. Z. Ciechanowska, hasło: Kruszyński Jan, [w:] Polski stownik biograficzny, t. 15, Wrocław 1970, s. 439-440. O J. Kruszyńskim wspomina F. Bentkowski, Historia literatury polskiej w spisie dzieł drukiem ogłoszonych, t. 1, Przedmowa, s. X. 
Samuel Bogumił Linde udostępnił mu spis ,pism polskich”, które wykorzystał w swoim Słowniku. Spis ten opracowany w oparciu o księgozbiór Ossolińskiego w Wiedniu, dostarczył także wiadomości w postaci rękopiśmiennych notatek bibliograficznych (również sporządzonych przez Lindego na podstawie wspomnianego księgozbioru) o cennych drukach. Dzięki Lindemu Bentkowski miał także okazję zapoznać się z rękopisem Dykcjonarza poetów Michała Hieronima Juszyńskiego $^{33}$.

Ponadto księgarz wileński Józef Zawadzki udostępnił Bentkowskiemu materiały do Dykcjonarza sławnych Polaków oraz zasobne zbiory swojej księgarni. Bentkowski wspominał, iż korzystał również z księgozbiorów prywatnych gorliwych zbieraczy piśmiennictwa - Kajetana Kwiatkowskiego ${ }^{34}$ czy Jerzego Wincentego Bandtkiego ${ }^{35}$, z dostępnym wówczas dorobkiem bibliograficznym Jana Andrzeja Załuskiego i Daniela Jana Janockiego. Uzyskał także pomoc ze strony brata Wincentego Bandtkiego - Jerzego Samuela Bandtkiego, który powierzył mu swą pracę dotyczącą literatury prawniczej. Po naniesieniu drobnych poprawek Bentkowski umieścił ją w drugim tomie Historii literatury polskiej. Od Aleksandra Chodkiewicza otrzymał informacje z dziedziny fizyki i chemii, natomiast o najstarszych dziejopisach polskich od Joachima Lelewela. Sporą część materiałów dostarczyli mu m.in. Jan Śniadecki, Ambroży Grabowski ${ }^{36}$, ale

${ }^{33}$ F. Bentkowski, Historia literatury polskiej..., t. 1, s. 62-63.

${ }^{34}$ Kajetan Kwiatkowski (1770-1852) był historykiem i zbieraczem książek, pisarzem politycznym, od roku 1805 członkiem Warszawskiego Towarzystwa Przyjaciół Nauk, gdzie podjął się opracowania czasów Władysława IV. Rękopis dziejów Władysława IV złożył Towarzystwu w roku 1814. Zgromadził w Warszawie księgozbiór liczący kilka tysięcy, złożony głównie z dzieł polskich i Polski dotyczących; składały się na niego druki z okresu reformacji, m.in. kilkadziesiąt rakowskich, broszury polityczne z czasów Sejmu Czteroletniego, odezwy i ulotki z czasów powstania kościuszkowskiego, literatura dramatyczna oraz tłumaczenia z XVIII wieku, także stare druki pochodzące z dawnych bibliotek klasztornych. Kwiatkowski zbierał również dzieła autorów greckich i rzymskich, przeważnie w wydaniach bibliofilskich oraz europejską literaturę klasyczną z XVIII i początku XIX wieku w kilku językach, głównie francuskim. W roku 1838 sprzedał swój księgozbiór Bibliotece Banku Polskiego w Warszawie. Obecnie wraz ze zbiorami Banku znajduje się on w Bibliotece Uniwersyteckiej w Warszawie. Kwiatkowski posiadał też zbiór rękopisów pochodzący z Archiwum Radziwiłłów w Nieświeżu, który liczył 96 rękopisów oraz luźne materiały z lat 1530-1776. Rękopisy te przeszły w ręce Działyńskiego, który w roku 1821 nabył je dla Biblioteki w Kórniku, gdzie pozostały do dziś. W roku 1829, za pośrednictwem Bentkowskiego, Kwiatkowski przedstawił Uniwersytetowi Warszawskiemu propozycję sprzedaży zbioru medali polskich; do transakcji doszło jeszcze tego roku, na rzecz Uniwersytetu nabyto 270 sztuk numizmatów. K. Pieńkowska, hasło: Kwiatkowski Kajetan, [w:] Stownik pracowników ksiązki polskiej, Warszawa Łódź, 1972, s. 493494; B. Krakowski, hasło: Kwiatkowski Kajetan, [w:] Polski słownik biograficzny, t. 16, Wrocław 1971, s. 356-358.

${ }^{35}$ F. Bentkowski, op. cit., t. 1, Przedmowa, s. IX-X. Zob. J. Korpała, Dzieje bibliografii w Polsce..., s. 107.

${ }^{36}$ Bentkowski w rozdziale literatury prawniczej zamieścił dzieło warszawskiego profesora 
miało to miejsce dopiero po ukazaniu się pierwszego tomu Historii literatury polskiej.

$\mathrm{Z}$ punktu widzenia bibliograficznego istotne było to, że Bentkowski wskazywane $\mathrm{w}$ swej pracy dzieła starał się opisywać $\mathrm{z}$ autopsji ${ }^{37}$. Jak sam stwierdził w Przedmowie do pierwszego tomu Historii literatury polskiej: ,, [... ] starałem się wszystkie dzieła własnemi oglądać oczyma” i dalej kontynuował: „,... ] skoro więc przy dziele jakowem żadnej nie przytaczam obcej powagi, dowodem jest, że sam je w ręku miałem [... ]"38. Natomiast w przypadku trudności z dotarciem do książek poprzestawał na opinii autorów, którzy o tych dziełach pisali lub o nich przynajmniej wzmiankowali. Jednak przy ich wyborze zachował pewne stopniowanie. Największą ,wiarę” dawał swym poprzednikom na polu bibliografii polskiej: Janowi Andrzejowi Załuskiemu, Szymonowi Starowolskiemu, Danielowi Janowi Janockiemu, Józefowi Sołtykowiczowi i innym, którzy pisząc o jakimś dziele, zaznaczali jednocześnie, czy zapoznali się z nimi osobiście, czy też znali je tylko z obcych opisów ${ }^{39}$. Ponadto wykorzystał: pochwały sławnych Polaków ogłaszane w „Rocznikach Towarzystwa Przyjaciół Nauk”, rozprawy teoretycznoliterackie czy biograficzno-literackie wstępy do poszczególnych wydań pisarzy i poetów, m.in. w edycji Tadeusza Mostowskiego.

Jak uznał Szperna, wydanie planowanego kompendium mogło pomóc Bentkowskiemu w ugruntowaniu jego pozycji w środowisku ówczesnych intelektualistów oraz w zdobyciu szacunku ze strony uznanych autorytetów, a wejście do ich wąskiego grona dawałoby mu w pewnym stopniu możliwość współuczestniczenia w kształtowaniu nowych poglądów i opinii naukowych co, jak się wydaje, w tamtej chwili było dla niego kwestią najważniejszą ${ }^{40}$. Do warsztatu, jaki zorganizował,

prawa J. W. Bandtkiego pt. De studio juris Polonici auctore, Warszawa 1806, które, jak pisze Bentkowski, Bandtkie „,pomnożywszy i udoskonaliwszy” umieścić w Historii literatury „zezwolił”. Zob. F. Bentkowski, op. cit., t. 1, s. 59.

37 Przy omawianiu dzieła Szymona Starowolskiego Scriptorum Polonicorum Hecatontas... Bentkowski podaje, iż „używał edycji Weneckiej”, która była najlepsza; wskazywał w przypadku innego dzieła tegoż polihistora, jak Polonia sive status regni Poloniae descriptio, iż jego drugie i czwarte wydanie znajdują się w bibliotece Liceum Warszawskiego, przy innych dziełach pisał także, że są w Bibliotece Liceum Warszawskiego. Zob. F. Bentkowski, op. cit., t. 1, s. 4-5, 8, 19.

${ }^{38}$ F. Bentkowski, op. cit., t. 1, Przedmowa, s. IX.

39 Bentkowski wyjaśnia: „,...] przestać na ten czas musiałem na powadze autorów, którzy o dziełach naszych bądź z umysłu pisali, bądź nawiasem wzmianki o nich czynią. Między temi zachowałem jednak pewne stopniowanie; największą w tej mierze wiarę daję Janockiemu, Załuskiemu, Sołtykowiczowi, którzy mówiąc o dziele jakowem, wyrażają natychmiast, czyli je mieli w ręku, lub je z obcych tylko opisów znają". F. Bentkowski, op. cit., t. 1, Przedmowa, s. IX, XI. Zob. J. Korpała, Zarys dziejów bibliografii w Polsce..., s. 56.

${ }^{40}$ T. Szperna, Kształtowanie się bibliograficznych zainteresowań Feliksa Bentkowskiego..., s. 72 . 
napływały coraz bogatsze materiały bibliograficzne od różnych zbieraczy, bibliografów, bibliofilów i uczonych erudytów, a zebrane dokumenty kilkakrotnie przekroczyły ramy podręcznika szkolnego. Ten fakt przesądził o sposobie realizacji zamówienia. Według Skręta, Bentkowski zajmował się początkowo piśmiennictwem polskim wyłącznie na potrzeby szkoły i miał zamiar napisać podręcznik historii literatury polskiej. Jednakże ogrom zgromadzonych materiałów spowodował, iż zdał sobie sprawę, że nie zdoła ich opracować, dlatego podjął decyzję o uporządkowaniu dokumentów pochodzących z różnych źródeł i - jak sam zapowiadał wydaniu całości drukiem. Tym samym zadecydował o porzuceniu pierwotnego zamiaru i zamiast podręcznika powstało obszerne dwutomowe dzieło, które stanowiło biobibliograficzne podsumowanie dotychczasowej wiedzy o całym polskim piśmiennictwie ${ }^{41}$.

Dopiero po zapoznaniu się z opiniami na temat opublikowanej pracy Bentkowski miał przystąpić do opracowania podręcznika szkolnego w postaci krótkiego rysu. Jednak tego planu nigdy nie udało mu się zrealizowaćc ${ }^{42}$.

Przytoczony powyżej program wykładów Bentkowskiego w Liceum Warszawskim informował pokrótce o zawartości i układzie dzieła, a uzupełnienie stanowił sam tytuł Historia literatury polskiej wystawiona $w$ spisie dziet drukiem ogtoszonych, z którego wynikało, iż autor pomijał nieopublikowaną do jego czasów spuściznę rękopiśmienną, a swą uwagę skupił nie na analizie, ale na wykazie starodruków. Na początku Historii... umieścił obszerną „,wiadomość o dziełach do historii literatury i bibliografii polskiej potrzebnych i ich pisarzach". Jak twierdził Korpała, była to pierwsza bibliografia bibliografii polskiej, a jednocześnie materiał do historii bibliografii w Polsce, uszeregowany w porządku chronologicznym, o czym sam autor pisał we wprowadzeniu do wspomnianego spisu: ,,[...] umieszczamy tu poczet dzieł [...] w porządku chronologicznym, wykazując oraz po większej części źrzódła i pomoce przy ułożeniu niniejszego pisma używane”. Jak podsumował Makowski, Bentkowski wymienił i omówił ponad sto źródeł polskich i obcych, na których się opar ${ }^{43}$. W „Wiadomościach...” znalazły się m.in. dzieła polihistora Krzysztofa Warszewickiego Reges, Sancti, Bellatores, Scriptores Poloni wydanego w Rzymie w 1601 roku (w którym znajduje się pierwszy drukowany spis pisarzy polskich liczący 27 nazwisk), dzieła Szymona Starowolskiego, Scriptorum Polonicorum Hecatontas..., dwa znamienne rękopisy Józefa Andrzeja Załuskiego, tj. Biblioteka historyków, polityków, prawników i innych autorów polskich lub

${ }^{41}$ R. Skręt, op. cit., s. 8.

42 S. Makowski, Feliks Bentkowski 1781-1852..., s. 117; J. Korpała, Dzieje bibliografii w Polsce..., s. 107; idem, Zarys dziejów bibliografii w Polsce..., s. 53.

${ }^{43}$ F. Bentkowski, op. cit., t. 1, s. 3; J. Korpała, Dzieje bibliografii w Polsce..., s. 107; S. Makowski, Feliks Bentkowski 1781-1852..., s. 117. 
o Polsce piszacych (które funkcjonowały wówczas w kilkunastu odpisach po różnych bibliotekach) oraz Magna bibliotheca polona universalis (główne 10-tomowe dzieło bibliograficzne) Daniela Jana Janockiego i Józefa Aleksandra Jabłonowskiego. Im to Bentkowski poświęcił najwięcej miejsca, jeśli chodzi o liczbę wymienionych prac czy informacji biograficznych. Pośród autorów prac omawianego spisu znaleźli się profesorowie szkół w Toruniu, Elblągu, Gdańsku, uniwersytetów Krakowskiego i Wileńskiego, jezuici, pijarzy, duchowni-kaznodzieje, biskupi, wojewodowie. W wykazie Bentkowskiego znalazły się ponadto czasopisma wydawane przez Wawrzyńca Mitzlera de Kolof w języku niemieckim i łacińskim „Warschauer Bibliothek oder gründliche Nachrichten alten als neuen Büchern und Schriften so wohl alten als neuen, so in Pohlen herausgekommen, auf das Jahr..." i „Acta literaria regni Poloniae et M. D. Lithuaniae Anno..."44. Charakter pracy Bentkowskiego w dużym stopniu określony został przez źródła, z których w Polsce wyrastała synteza historycznoliteracka, a mianowicie: bibliografię, klasycystyczną poetykę, związaną z nią krytykę literacką oraz żywotopisarstwo, które do czasów jemu współczesnych występowało w formie dykcjonarzy czy elogiów ${ }^{45}$.

Bentkowski, wydając Historię literatury polskiej, miał świadomość, iż jego dzieło wymaga jeszcze dopracowania, wzbogacenia i licznych uzupełnień. Stąd też zwracał się z prośbą, by „ci co więcej wiedzą” swych opinii krytycznych „udzielić racz[yli]”, skierowali je do niego czy to na łamach czasopism, czy to bezpośrednio w listach lub do księgarni Zawadzkiego ${ }^{46}$.

Ukazanie się Historii literatury polskiej spowodowało dyskusję naukową nad jej tytułem. Jan Śniadecki w liście do Bentkowskiego z 17 stycznia 1814 roku jako pierwszy zwrócił uwagę na niezgodność tytułu z treścią i układem dzieła, tym samym rozpoczynając dyskusję nad pojęciem „literatura”, jego znaczeniem i zakresem ${ }^{47}$. W odpowiedzi Bentkowski wyjaśnił, iż termin ten odniósł raczej do znaczenia w języku niemieckim aniżeli francuskim, stąd istotą jego dzieła jest właściwa bibliografia ${ }^{48}$. Joachim Lelewel wynik tej dyskusji ocenił, stwierdzając,

\footnotetext{
44 Zob. F. Bentkowski, op. cit., t. 1, s. 49-50.

${ }^{45}$ Choćby Dykcjonarz poetów polskich H. Juszyńskiego czy Scriptorum Polonicorum Hecatontas... Sz. Starowolskiego nazywane przezeń w Przedmowie elogium; S. Makowski, Feliks Bentkowski $1781-1852 \ldots$, s. 117.

${ }^{46}$ Bentkowski pisał: „Ale zapomnieć nie trzeba, iż materiały te wielkiego uzupełnienia, pomnożenia i sprostowania potrzebują. Każdy piszący oczekuje krytyki, i jeżeli słuszna, przyjąć ją powinien nie tylko bez obrazy, ale $\mathrm{z}$ wdzięcznością. W takowej myśli wyglądam jej ja także, i upraszam o nią szczerze, bo wiem, że dzieło tego rodzaju za pierwszem zjawieniem się bez błędów być nie może". Zob. F. Bentkowski, op. cit., t. 1, Przedmowa, s. XII-XIII.

${ }^{47}$ M. Baliński, Pamiętniki o Janie Śniadeckim, jego życiu prywatnem i publicznem i dziełach jego, t. 2, Wilno 1865, s. 394-395.

${ }^{48}$ List Feliksa Bentkowskiego do Jana Śniadeckiego z 26 lutego 1814 roku. Bentkowski, dzię-
} 
że „Bentkowski dał dziełu swojemu niestosowny tytuł przez to, że go nazwał historią literatury polskiej"49.

Do dyskusji zapoczątkowanej przez Śniadeckiego włączył się także Grodek, który w swym artykule zatytułowanym $O$ znaczeniu, celu $i$ osnowie literatury w powszechności próbował wyjaśnić pojęcia „literatura” i „literat”. Także Jerzy Maksymilian Ossoliński w liście z 30 stycznia 1823 roku do Adama Czartoryskiego podzielił opinię Lelewela, zwracając uwagę, iż Bentkowski „pokrzywdził swoje dzieło przesadzonem na czele hasłem: Historia Literatury Polskiej" ${ }^{\prime 50}$. Zdaniem Tadeusza Mikulskiego dyskusja ta okazała się potrzebna, gdyż zamknęła „okres wahań i nieporozumień”, jeśli chodzi o badania historycznoliterackie ${ }^{51}$.

Śledząc związki historii literatury i bibliografii, można wskazać znaczące jej momenty. Wspominany wcześniej polihistor Szymon Starowolski, autor Scriptorum Polonicorum Hecatontas, postawił znak równości między tymi naukami. Jak uważa Mikulski, obok dzieła Krzysztofa Warszewickiego, dzieło Starowolskiego stanowiło ważną prolegomenę do późniejszej pracy Józefa Andrzeja Załuskiego. Wiek XVIII przyniósł erudytę i praktyka na polu bibliografii właśnie w osobie Załuskiego, który dostrzegał już, że bibliografia nie jest jednoznaczna z historią literatury ${ }^{52}$.

Jednakże proces wyodrębniania się syntezy historycznoliterackiej można było obserwować dopiero w dziele Bentkowskiego, w którym element bibliograficzny współgrał z elementami historycznym, biograficznym i estetycznym. Według Makowskiego, u Bentkowskiego bibliografia przeważa nad elementami syntetycznych ocen pisarzy i okresów, choć jednak próby rozważań historycznoliterackich dają się zauważyćs ${ }^{53}$.

kując Śniadeckiemu za uznanie dla jego Historii literatury..., tłumaczy, iż z powodu licznych ,zatrudnień" go zajmujących, dzieło to było tworzone w pośpiechu i pozostawia wiele do życzenia, stąd wszelkie uwagi i sprostowania przyjmuje z wdzięcznością od znajomych, o co prosił w Przedmowie. Zwraca uwagę Śniadeckiemu, iż mimo jego apelu, jak dotąd uzyskał jedynie list od przyjaciela z Krakowa z notatkami bibliograficznymi i kilka drobnych uwag od znajomych, a Śniadeckiego prosi o dalsze uwagi w tej kwestii. Odpowiadając Śniadeckiemu, Bentkowski pisze: „Co się tyczy wyrazu literatury, wziąłem ja go raczej w znaczeniu niemieckiem niż francuskiem, z tego powodu właściwa Bibliografia jest istotą pisma mego". Zob. M. Baliński, op. cit., s. 396-397.

49 J. Lelewel, Bibliograficznych ksiag dwoje, Wilno 1826, t. 2, s. 160.

${ }^{50}$ List $w$ przedmiocie Historyi Literatury Polskiej pisany z Wiednia przez Józefa Maximiliana z Tęczyna Hrabię Ossolińskiego do księcia A. C., drukowany w „Dzienniku Warszawskim” 1825, t. 2, s. 48 .

51 T. Mikulski, Historia literatury wobec zagadnień księgoznawstwa, [w:] Studia nad ksiażka poświęcone pamięci Kazimierza Piekarskiego, t. 1 serii: Ksiązka w dawnej kulturze polskiej w oprac.

K. Budzyka, Wrocław 1951, s. 68.

52 T. Mikulski, op. cit., s. 65-66.

53 S. Makowski, Feliks Bentkowski 1781-1852..., s. 117-118. 
Mimo że w Historii literatury polskiej Bentkowskiego elementy historycznoliterackie ustępowały jeszcze miejsca bibliografii czy biografii, to działo się to w zasadzie po raz ostatni. Jak pisze Mikulski, najważniejszym rezultatem jego dzieła, aczkolwiek nieoczekiwanie dla autora, było to, iż „związek tożsamości między historią literatury a bibliografią został wyraźnie przerwany"54.

W czasach Bentkowskiego liczni systematycy nauk w swych schematach klasyfikacyjnych utożsamiali historię literatury z historią piśmiennictwa, włączając do niej także bibliografię. Po Historii literatury polskiej Bentkowskiego doszło do samookreślenia się historii literatury i oddzielenia jej od bibliografii. Zatem historia literatury przez określenie swojego przedmiotu i celu badań odłączyła się wówczas jednoznacznie od bibliografii, żywotopisarstwa i krytyki literackiej, z których wzięła swój początek i z którymi przez długi czas ją utożsamiano ${ }^{55}$.

Należy podkreślić, że kiedy Bentkowski przystąpił do opracowywania Historii literatury polskiej, był młodym, trzydziestoletnim pedagogiem i początkującym naukowcem. Jak uważa Korpała, nie miał przed sobą poważniejszych poprzedników. Odmiennego zdania jest Makowski, dla którego pierwszym podręcznikiem historii literatury był, wspomniany już przekład z francuskiego Françoisa de Jouvénal de Carlencas Historia nauk wyzwolonych, a wzory mógł znaleźć tylko w literaturach obcych. Sam fakt, że Bentkowski studiował na uniwersytecie niemieckim skłaniał go ku temu, by iść szlakiem wytyczonym przez polihistorów, encyklopedystów i erudytów, jakich sporo pojawiło się w Niemczech w drugiej połowie XVIII i na początku XIX wieku. A zatem zrozumiałe jest, że jako wychowanek szkoły niemieckiej, przesiąknięty niemiecką kulturą naukową, musiał szukać wzorów w piśmiennictwie niemieckim. Dlatego w koncepcji swojego dzieła wzorował się na teoretykach i historykach, takich jak Krzysztof August Heumann, Girolamo Tiramboschi, Ludwik Wachler, Jan G. Eichorn czy Juliusz Eduin $\mathrm{Koch}^{56}$.

Według Bentkowskiego Historia literatury miała pełnić rolę ogólnej bibliografii i zajmować się całokształtem piśmiennictwa ze wszystkich dziedzin sztuki i wiedzy. Przyjąwszy tę zasadę, tom drugi dzieła poświęcił naukom społecznym i matematyczno-przyrodniczym. Jak uznał Korpała, Bentkowski w sposobie grupowania materiału bibliograficznego i komentowaniu go nie był oryginalny. $\mathrm{Na}$ układzie dzieła zaważył wpływ Wachlera i Heumanna. Drugi z nich zalecał, by materiał opracowywać w układzie chronologicznym bądź też każdą dyscyplinę lub każdy rodzaj literacki z osobna. Nowatorstwo Heumanna polegało na tym, iż starał się fakty z dziejów umysłowości wyjaśniać poprzez różnorodne przyczyny,

${ }^{54}$ T. Mikulski, op. cit., s. 68.

55 S. Makowski, O najdawniejszych podręcznikach historii literatury polskiej..., s. 25.

56 J. Korpała, Dzieje bibliografii w Polsce..., s. 105-113; S. Makowski, O najdawniejszych podręcznikach historii literatury polskiej..., s. 26; T. Sterzyński, op. cit., s. 3. 
biorąc pod uwagę warunki sprzyjające lub szkodliwe, innymi słowy doszukiwał się społecznego podłoża zjawisk kulturowych. Takie podejście napotykamy również u Bentkowskiego ${ }^{57}$. Czerpiąc wzory z Historii literatury Eichorna, wyrobił sobie pogląd na przedmiot i cel historii ${ }^{58}$. Za Tiramboschim, przedstawicielem encyklopedyzmu włoskiego w literaturze, umieszczał w swym wykazie obok dzieł autorów wybitnych także utwory pomniejsze ${ }^{59}$. Z Powszechnej historii literatury Wachlera $^{60}$, kontynuatora poglądów Heumanna, przyjął koncepcję historycznego ujmowania literatury, tj. łączenia literatury i badań nad nią z całokształtem życia

${ }^{57}$ Krzysztof August Heumann (1681-1763) w swym podręczniku pt. Conspectus Reipublicae Literariae sive ad Historiam Literariam iuventuti studiosae aperta a..., Hanower 1718 dokonał przeglądu literatury powszechnej na 170 stronach. Wykład jest zwięzły, obejmuje najważniejsze wiadomości i przynosi niejedną niespodziankę w sposobie naukowego ujęcia. W ciągu XVIII wieku jego książka była bardzo rozpowszechniona, o czym świadczy liczba jej wydań, bowiem do roku 1763 było ich siedem. M. Mann, op. cit., s. 48-50; J. Korpała, Zarys dziejów bibliografii w Polsce..., s. 56.

58 Jan G. Eichhorn (1752-1827) wykładał historię literatury i kultury początkowo w Jenie, potem w Getyndze, jego wykładów słuchał Wachler. W roku 1795 pod egidą Eichhorna zawiązało się towarzystwo uczonych w celu wspólnego opracowania całkowitej historii piśmiennictwa; tytuł ogólny dzieła brzmiał Geschichte der Kunste und Wissenschaften seit der Wiederherstellung derselben bis an das Ende des XVIII Jahrhunderts, von einer Gesellschaft gelehrter Manner augearbeitet. Eichhorn podjął się opracowania kierunku ogólnego, w roku 1796 wydał tom pierwszy pracy pt. Allgemeine Geschichte der Cultur und Litteratur des neueren Europa, w roku 1799 wyszedł tom drugi i na tym urwało się zamierzone dzieło. Przystąpił jednak do nowego dzieła wyłącznie o literaturze. Powstał podręcznik Literargeschichte, Monachium 1799 oraz nieco później obszerna historia literatury i nauk od czasów najdawniejszych do końca XVIII wieku pt. Geschichte der Litteratur non ihrem Ursprunge nis auf die neueste Zeit, Göttingen 1805-1812 w sześciu tomach. Zob. M. Mann, op. cit., s. 109-111.

59 Hieronim Tiramboschi (1731-1794), jezuita, nauczyciel wymowy, od roku 1770 bibliotekarz książęcy w Modenie podjął się ułożenia w jedną całość wiadomości o piśmiennictwie włoskim, a także rzymskim. Rezultatem tego było ogromne dzieło Historia literatury włoskiej wydawane od 1772 do 1781 roku w czternastu tomach (Storia della letteratura Italiano di Girolamo Tiramboschi). Wydanie drugie 1787-1793 liczyło już tomów 16. W dziele swym Tiramboschi, o czym sam pisze, zastosował porządek chronologiczny podzielony na krótsze okresy po dwa lub więcej wieków, a w ramach każdej z tych epok omawiał poszczególne nauki z osobna pod względem ich rozwoju. Dzieło to stanowi dużą wartość dla badaczy literatury włoskiej nie ze względu na zastosowaną metodę czy ocenę estetyczną, ale $\mathrm{z}$ uwagi na ogromną liczbę opracowanych $\mathrm{w}$ niej biografii. O rozmiarach tej pracy świadczy skorowidz imion stanowiący osobny tom. Zob. M. Mann, op. cit., s. $60-63$.

${ }^{60}$ L. Wachler, Versuch einer Allgemeinen Geschichte der Litteratur. Cztery tomy 1793, 1794, 1796, 1801 doprowadzone do połowy wieku XVII. Dla Wachlera historia literatury „ma być systematycznym zbiorem faktów, opowieścią o przemianach, wznoszeniu się i upadku wszystkich umiejętności, wyjaśnieniem przyczyn tego i skutków". Za cel swej Powszechnej historii literatury postawił podawanie wiadomości wyłącznie o pisarzach znaczących, którzy wywarli wpływ na całą literaturę bądź na jej stan w danym kraju. Ponadto miał zamiar podawać tylko wyniki badań i rzeczy pewne, pomijając kwestie sporne. Każdy charakteryzowany okres poprzedzał wstępem. Dzięki znajomości historii politycznej i świetnej orientacji w zdobyczach cywilizacyjnych trafnie 
umysłowego narodu w określonym momencie dziejowym. Koncepcję tę przeniósł na grunt ojczysty i dostosował do jego realiów.

Według Sterzyńskiego fakt wzorowania się Bentkowskiego na dziele Wachlera nie budzi wątpliwości ze względu na znaczną analogię jego Historii literatury polskiej z ogólnym wstępem historyczno-kulturalnym niemieckiego podręcznika i z jego ujęciem historycznym ${ }^{61}$. Świadczy o tym zawarta $w$ tomie pierwszym Historii literatury polskiej część pierwsza o charakterze opisowym zatytułowana $O$ stanie nauk $w$ Polszcze od zaprowadzenia chrześcijaństwa az do naszych czasów... Bentkowski, podobnie jak Wachler w Powszechnej historii literatury, $\mathrm{w}$ rozdziale pierwszym przedstawił w zarysie czynniki ułatwiające, w drugim zaś utrudniające rozwój oświaty i piśmiennictwa w Polsce. Jednak sam przyznawał, że uczynił to świadomie w sposób zwięzły ${ }^{62}$. Sterzyński postawił tezę, iż Bentkowski, szukając wzorów dla swej przyszłej Historii literatury polskiej spośród nielicznych nowszych niemieckich prac historycznoliterackich, obok dzieł Wachlera i Eichorna mógł brać pod uwagę także dzieła Kocha, na co wskazywał już Korpała. Sterzyński, po przeanalizowaniu struktury i układu dzieła Kocha z zakresu literatury niemieckiej Compendium der deutsche Literatur geschichte von den ältesten Zeit bis auf Lesings Tod... (Berlin 1790-1798), wysnuł wniosek, iż podręcznik niemieckiego literaturoznawcy wpłynął na ogólną konstrukcję dzieła Bentkowskiego, zwłaszcza na jego część bibliograficzną. Badacz uzasadniał to tym, że w ówczesnym piśmiennictwie niemieckim nie było dzieła, do którego konstrukcja bibliograficzna Historii literatury polskiej Bentkowskiego byłaby bardziej zbliżona. Zdaniem Sterzyńskiego była ona poświęcona wyłącznie literaturze pięknej, a w zamierzeniu jej autora miała stanowić podręcznik bibliograficzny dla celów pedagogicznych ${ }^{63}$.

Podsumowując rozważania, warto zauważyć, że Feliks Jan Bentkowski, jako uczeń filologicznej szkoły Augusta Fryderyka Wolffa, zafascynowany niemiecką kulturą naukową i zarażony pedantyzmem niemieckich uczonych, ponadto obezna-

opisywał epoki, potrafił wskazywać warunki i wpływy, którym podlegała twórczość i nauka. Zob. M. Mann, op. cit., s. 107-108.

61 T. Sterzyński, op. cit., s. 34-35.

${ }^{62}$ F. Bentkowski, op. cit., t. 1, Przedmowa, s. VIII; S. Makowski, Feliks Bentkowski 1781$1852 .$. , s. 118. Wachler w swym dziele Versuch einer Allgemeinen Geschichte der Literatur (Lemgo 1793-1801, 4 tomy) położył duży nacisk na ogólne charakterystyki epok, z uwzględnieniem okoliczności wspierających lub tamujących rozwój piśmiennictwa. W obszernym wstępie jako okoliczności sprzyjające omawiał kolejno: wzrost kultury stanu średniego, wpływ reformacji, mecenat, rozwój zakładów naukowych, powstanie towarzystw naukowych, wreszcie rozwój czasopiśmiennictwa i bibliotek. Przechodząc do przeszkód, wymienił ucisk polityczny i zamieszki wewnętrzne, wojny, szerzenie się przesądów, cenzurę kościelną oraz wpływ jezuitów. Zob. T. Sterzyński, op. cit., s. 30,33 .

${ }^{63}$ T. Sterzyński, op. cit., s. 25-30. 
ny z zagranicznym ruchem naukowym, a przede wszystkim z zamiłowania historyk obdarzony samorodnym zmysłem krytycznym, miał wiele powodów ku temu, by stać się właściwym twórcą nowej dyscypliny naukowej - historii literatury polskiej. Znalazł się bowiem pod wpływem ruchu z pobudek patriotycznych, tj. z miłości do utraconej ojczyzny, i ruch ten natchnął go do stworzenia pomnikowego dzieła naukowego owej epoki, jakim była dwutomowa Historia literatury polskiej wystawiona $w$ spisie dziet drukiem ogłoszonych wydana w Warszawie i w Wilnie w 1814 roku, nakładem drukarza wileńskiego i warszawskiego Józefa Zawadzkiego ${ }^{64}$.

Należy także przypomnieć, iż w 2014 roku przypada znacząca, dwusetna rocznica ukazania się na rynku księgarskim tego wyjątkowego dzieła, niezwykle istotnego, zarówno dla dziejów bibliografii, jak i historii literatury polskiej. Bentkowski dedykował je „z najgłębszym uszanowaniem” jako „najniższy sługa” księciu Adamowi K. Czartoryskiemu, oddając je do druku w Warszawie 18 grudnia $1813 \mathrm{roku}^{65}$.

Zastanawiający jest natomiast fakt, że oba tomy Historii literatury polskiej zostały wznowione, pierwszy i jedyny raz, w roku 1982 w nakładzie 1300 sztuk techniką fotoofsetową na podstawie egzemplarza udostępnionego przez Bibliotekę Narodową. Samą zaś inicjatywę ponownej edycji omawianego dzieła należy przypisać Zjednoczeniu Księgarstwa Polskiego, które zleciło to zadanie Wydawnictwom Artystycznym i Filmowym ${ }^{66}$.

${ }^{64}$ Ibid., s. 27.

${ }^{65}$ Zob. F. Bentkowski, op. cit., t. 1. Dedykacja znajduje się na osobnej nieliczbowanej stronie, poprzedzając Przedmowę.

${ }^{66}$ T. Szperna, Historia literatury polskiej Feliksa Bentkowskiego w oczach wspótczesnych i potomnych. Jej recepcja, wptyw i znaczenie, „Acta Universitatis Lodziensis. Folia Librorum” 2001, nr 10, s. 36. 